\title{
Burdigalian-Langhian foraminifera of the northwest High Zagros Thrust Belt, southwest Iran
}

\author{
Asghar Roozpeykar ${ }^{1}$, Iraj Maghfouri Moghaddam ${ }^{1 *}$, Mehdi Yaazdi ${ }^{2}$, \\ Bijan Yousefi ${ }^{1}$ \\ ${ }^{1}$ Department of Geology, Faculty of Science, Lorestan University, Lorestan, Iran, \\ ${ }^{2}$ Department of Geology, Faculty of Science, University of Isfahan, Iran \\ * corresponding author; e-mail: maghfouri.i@lu.ac.ir
}

\begin{abstract}
The foraminiferal contents of the lower-middle Miocene succession exposed in three sections in north Nur Abad on the northwestern side of the High Zagros Thrust Belt were studied. Assemblages of larger foraminifera from these sections can be referred to Zone SBZ 25 (and the Miogypsina globulus and Miogypsina intermedia subzones), which correlates with the Burdigalian Stage. For the first time, planktonic foraminifera documented from the Nur Abad area document Langhian deposits in the High Zagros, the upper 20 metres of the upper Sayl Cheshmeh section being characterised by the occurrence of planktonic foraminifera such as Globigerina concinna (Reuss), Globigerina diplostoma (Reuss), Globigerinoides obliquus (Bolli), Orbulina bilobata (d'Orbigny) and O.universa (d'Orbigny). This association characterises the Orbulina suturalis Interval Zone.
\end{abstract}

Key words: Miocene, biostratigraphy, correlation, protists, Middle East

\section{Introduction}

During the Oligo-Miocene, present-day Iran was part of a seaway that connected the western and eastern Tethys (Reuter et al., 2008). Marine strata laid down here can be divided into three parts, namely the inter-basin deposits of the Asmari Formation (Zagros Orogenic Belt), the Qom Formation (extending into the central Iran back-arc, Urumieh-Dokhtar magmatic arc and Sanandaj-Sirjan fore-arc) and the Makran flysch deposits in southeast Iran (Berberian \& Yasini, 1983). Connective events with the Tethys Ocean resulted in units evolving in similar ways, although these were located in different climatic zones and were influenced by various tectonic pulses. These widespread successions are composed of source, reservoir and cap rocks and form prolific petroleum systems in Iran, especially in the Zagros Orogenic Belt (Motiei, 1993; Abbasi et al., 2020). Despite the economic importance of the Asmari Formation, its stratigraphy is not well understood; most previous studies of this unit are limited to the southern parts of the Zagros Orogenic Belt. However, surprisingly little information is available concerning the different biostratigraphical properties of the Asmari Formation in the north of the Zagros Orogenic Belt. In previous studies of Oligo-Miocene deposits in Iran, the age of the Asmari and Qom formations was defined as Rupelian to Burdiga- 


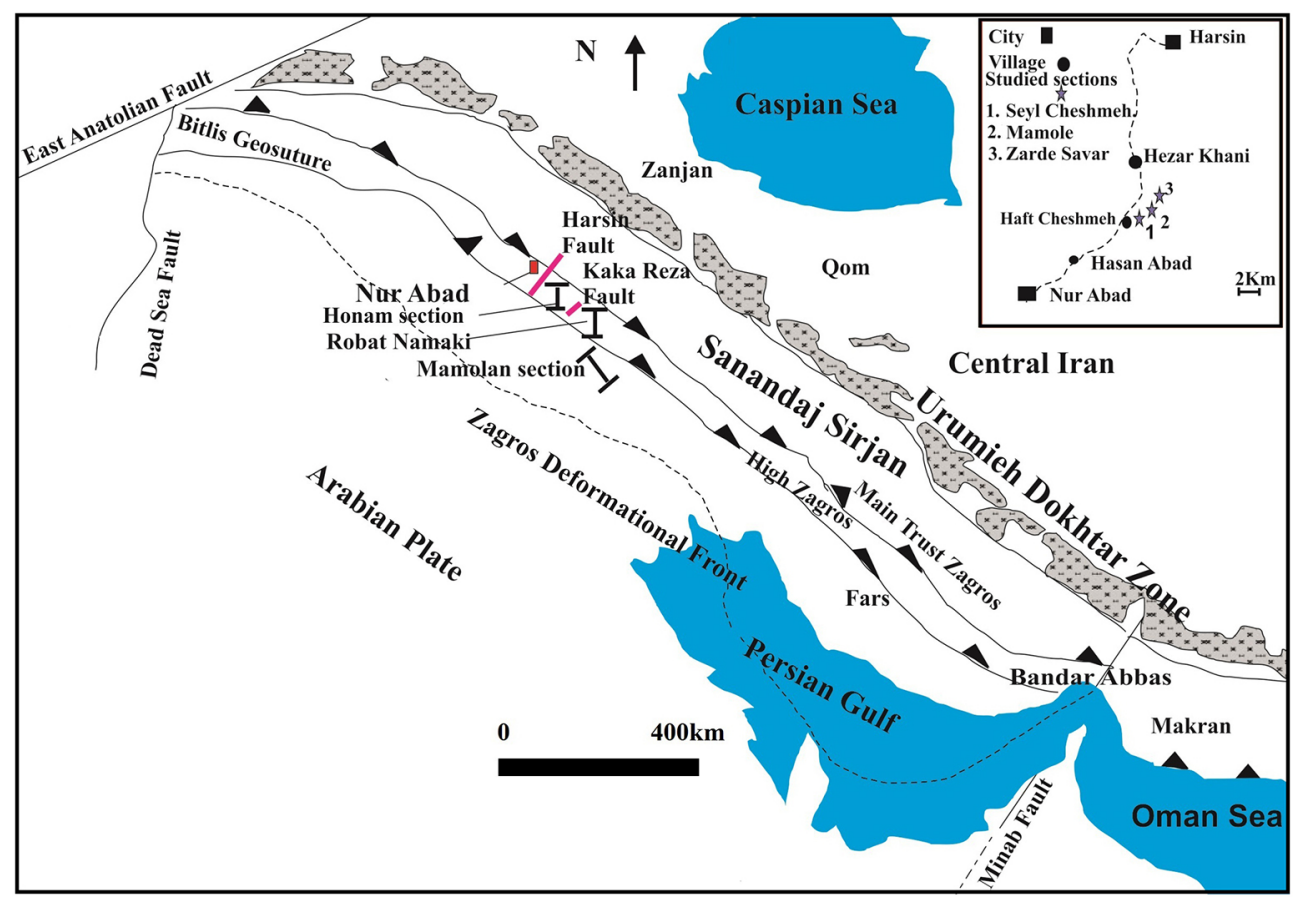

Fig. 1. Geographical map of the study area, showing localities studied and correlated in the present paper.

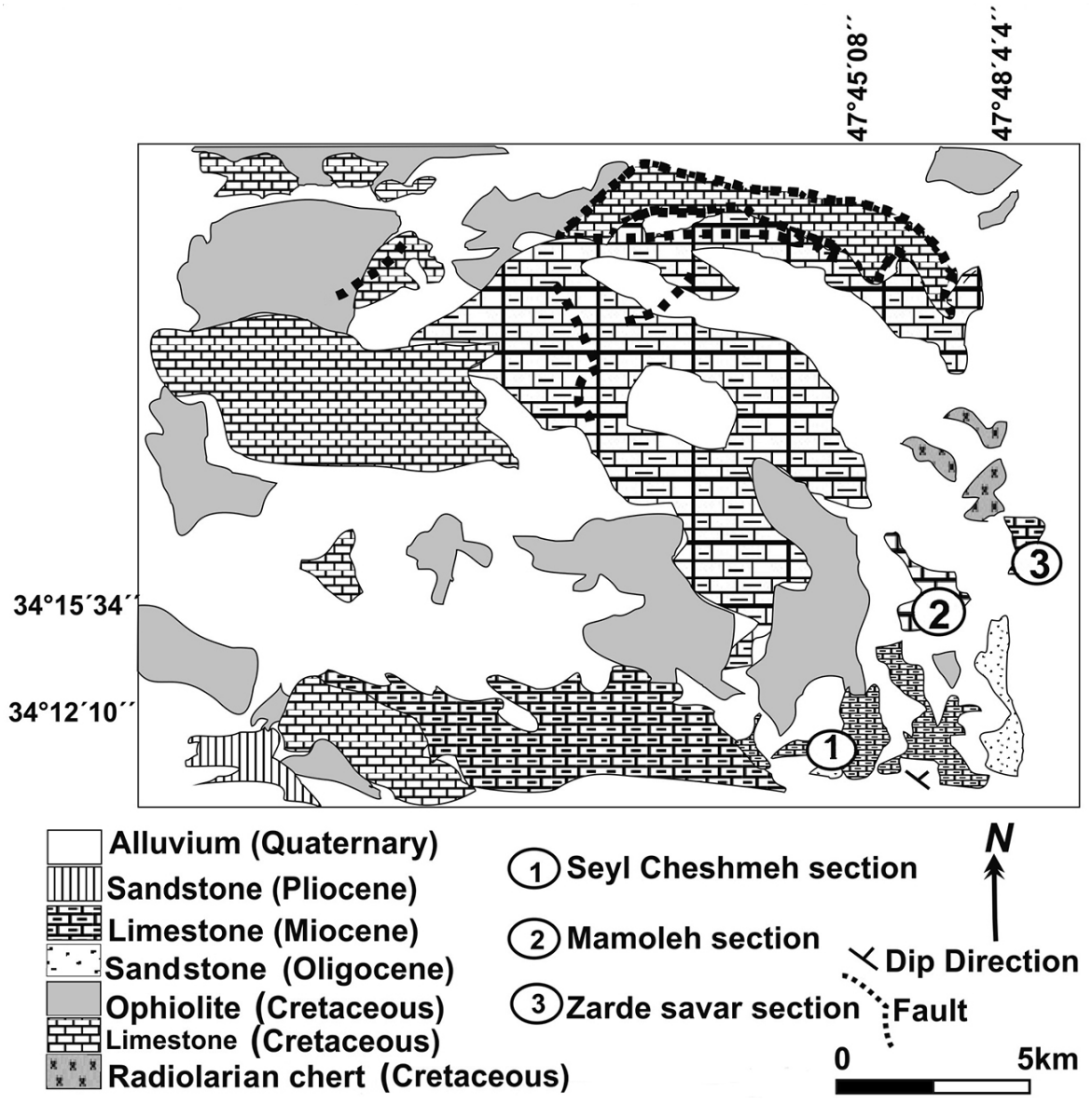

Fig. 2. Geological map of the study area (Shahidi \& Nazari, 1997). 
lian (Thomas, 1950, 1952; James \& Wynd, 1965), but more recently, Daneshian \& Ghanbari (2017) have recorded pelagic sediments of Langhian age (Qom Formation) in the Zanjan area of north-central Iran. Therefore, like the Qom Formation, there is a chance that post-Burdigalian strata are represented in the Asmari Formation. In view of this, the main objectives of the present study are, in addition to a lithostratigraphical classification, to establish a high-resolution biostratigraphical classification based on both planktonic and large benthic foraminifera of the Miocene carbonate platform in the High Zagros Thrust Belt. Our biostratigraphical analysis is based mainly upon comparisons of the larger benthic and small planktonic foraminiferal assemblages recorded from the study area with the well-known assemblages of the western Tethys and circum-Mediterranean areas, which puts the Lower Miocene strata of the High Zagros Thrust Belt in a global biochronological framework.

\subsection{Regional stratigraphy}

The Zagros Orogenic Belt formed after closure of the Neo-Tethys Ocean between the margin of Arabia and the Eurasian continent (Koop \& Stoneley, 1982). During the Late Cretaceous, the Zagros Orogenic Belt was divided into two basins (Sherkaty \& Letouzey, 2004), namely the High Zagros Thrust Belt (HZTB) and Zagros Fold-Thrust Belt (ZFTB). The HZTB is a narrow thrust belt, measuring up to $80 \mathrm{~km}$ in width, with a NW-SE trend. It is currently seismically active along a few segments and is characterised by high mountains, with a maximum elevation of about 3,000 metres in northwest Zagros, and overthrust anticlines that expose deep-lying sedimentary formations (Khadivi et al., 2012). The sections studied are located in the northwest HZTB, between the Main Zagros Thrust and the High Zagros Fault (Fig. 1).

In this area, deposits assigned to the Asmari Formation comprise medium- to thick-bedded limestones, sandy limestones and sandstones (Mamole: $82 \mathrm{~m}$ thick; Sayl Cheshmeh: $74 \mathrm{~m}$ thick; Zard Savar: $58 \mathrm{~m}$ thick). The lower and upper boundaries of the Asmari Formation are unconformable, with Oligocene deposits and Pliocene conglomerates, respectively (Fig. 2).

\section{Material and methods}

The main biogenic components of the Asmari Formation comprise different biota, including larger benthic foraminifera (LBF) and small planktonic foraminifera $(\mathrm{PF})$. In order to study the former and their internal structures, 74 thin sections were prepared. Planktonic forms were identified in washed residues of 47 soft-rock samples in the sections studied. After washing, samples were dried and put in special cellules; the planktonic foraminifera in these samples were handpicked under a binocular and subsequently studied by scanning electron microscopy.

\section{Biostratigraphy}

Based on foraminiferal distribution (Fig. 3), the following assemblage zones are recognised (Figs 4-6).

1. Indeterminate zone 1: This zone spans 10 metres in the basal Miocene deposits of the Mamole section. In view of the fact that we unable to find any index microfossils, comments on the age of this zone are difficult, which explains why this is here referred to as an indeterminate zone. Based on the absence of Borealis melo (Fichtel \& Moll, 1798), this part of the sequence was dated as late Aquitanian in some earlier studies (Agard et al., 2011), but we consider ecological conditions to have been responsible for this absence, because these levels are rich in species of the genera Elphidium de Montfort, 1808, Ammonia Linnaeus, 1758 and of miliolids. These taxa represent the predominance of a limited and unstable marginal-marine environment under oscillations or salinity reduction and an increased supply of organic matter into the basin (Murray, 1991). Since species of Miogypsina (Sacco, 1893) and Borelis (Montfort, 1808) live under normal marine conditions and cannot tolerate oscillations or salinity reduction, ecological conditions are here favoured to explain the absence of species of these characteristic genera.

2. Larger benthic foraminiferal zone SBZ 25: This biozone is defined by the first occurrence (FO) of Miogypsina globulina (Michelotti, 1841) at the base and the last occurrence (LO) of $M$. intermedia (Drooger, 1952) at the top. It can be divided into two subzones; those of M. globulina and $M$. intermedia.

2a. M. globulina Subzone: This is defined by the FO of M. globulina at the base and the FO of M. intermedia at the top. The former is regarded as a common global index for the Burdigalian Stage (Özcan \& Less, 2009), its FO coinciding with the base of the stage and the base of zone SBZ 25 in the Mediterranean (Cahuzac \& Poignant, 1997). This subzone is correlated with the Up- 


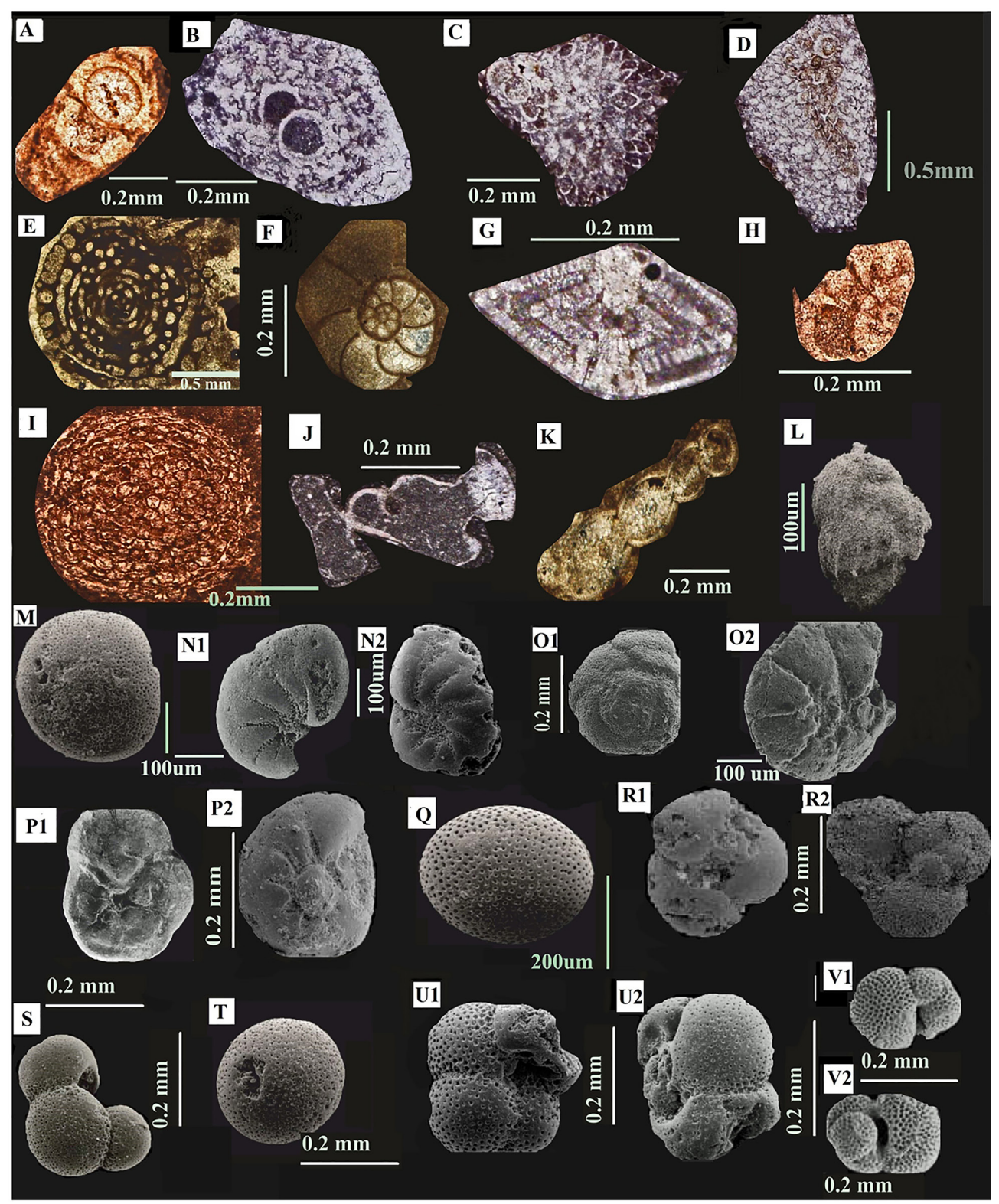

Fig. 3. Photomicrograph of foraminifera recognised in sections studied: A - Miolepidocyclina excentrica (Silvestri), axial section, Mamole section, sample no. 25; B - Miolepidocyclina burdigalensis (Gümbel), equatorial section, Mamole section, sample no. 51; C - Miogypsina intermedia (Drooger), equatorial section, Zardeh Savar section, sample no. 56; D - Miogypsina globulina (Michelotti), subaxial section, Zarde Savar Section, sample no. 16; E - Borelis melo curdica (Reichel), equatorial section, Sayl Cheshmeh section, sample no. 11; F - Lobatula lobatula (Walker and Jacob), equatorial section, Zarde Savar section, sample no. 1; G - Elphidium crispum (Linnaeus), axial section, Sayl Cheshmeh section, sample no. 12; H - Ammonia beccarii (Linnaeus, 1758), Axial section, Mamole section, Sample no. 20; I - Planorbulina sp., transverse section, Mamole section, sample no. 23; J - Haddonia sp., axial section, Sayl Cheshmeh section, sample no. 7; K - Nodosaria sp., axial section, Sayl Cheshmeh section, sample no. 14; L - Uvigerina cf. acuminata (Hosius), Sayl Cheshmeh section, sample no. 23, lateral view; M - Orbulina suturalis (Brönnimann), Syal Cheshmeh section, sample no. 35, umbilical view; N1, N2 - Nonion commune (d'Orbigny), Sayl Cheshmeh section, sample no. 35, dorsall and umbulical views; O1, O2 - Ammonia beccarii (Linnaeus), Mamole section, sample no. 20, in dorsal and umbilical views; P1, P2 - Ammonia parkinsoniana (d'Orbigny), Sayl Cheshmeh section, sample no. 3, umbilical and dorsal views; Q - Orbulina universa (d'Orbigny), Seil Cheshmeh section, sample no. 35, lateral view; R1, R2 - Globigerinoides tenellus (Parker), Sayl Cheshmeh section, sample no. 35, in dorsal and umbilical views; S - Hastigerina siphonifera (d'Orbigny), Sayl Cheshmeh section, sample no. 35, lateral view; T - Orbulina bilobata (d'Orbigny), Sayl Cheshmeh section, sample no. 105, umbilical view; U1, U2 - Globigerina diplostoma (Reuss), Sayl Cheshmeh section (no. 3), sample no. 35, umbilical and lateral views; V1, V2 - Trilobatus trilobus (Reuss), Sayl Chesmeh section, sample no. 31, in dorsal and umbilical views. 


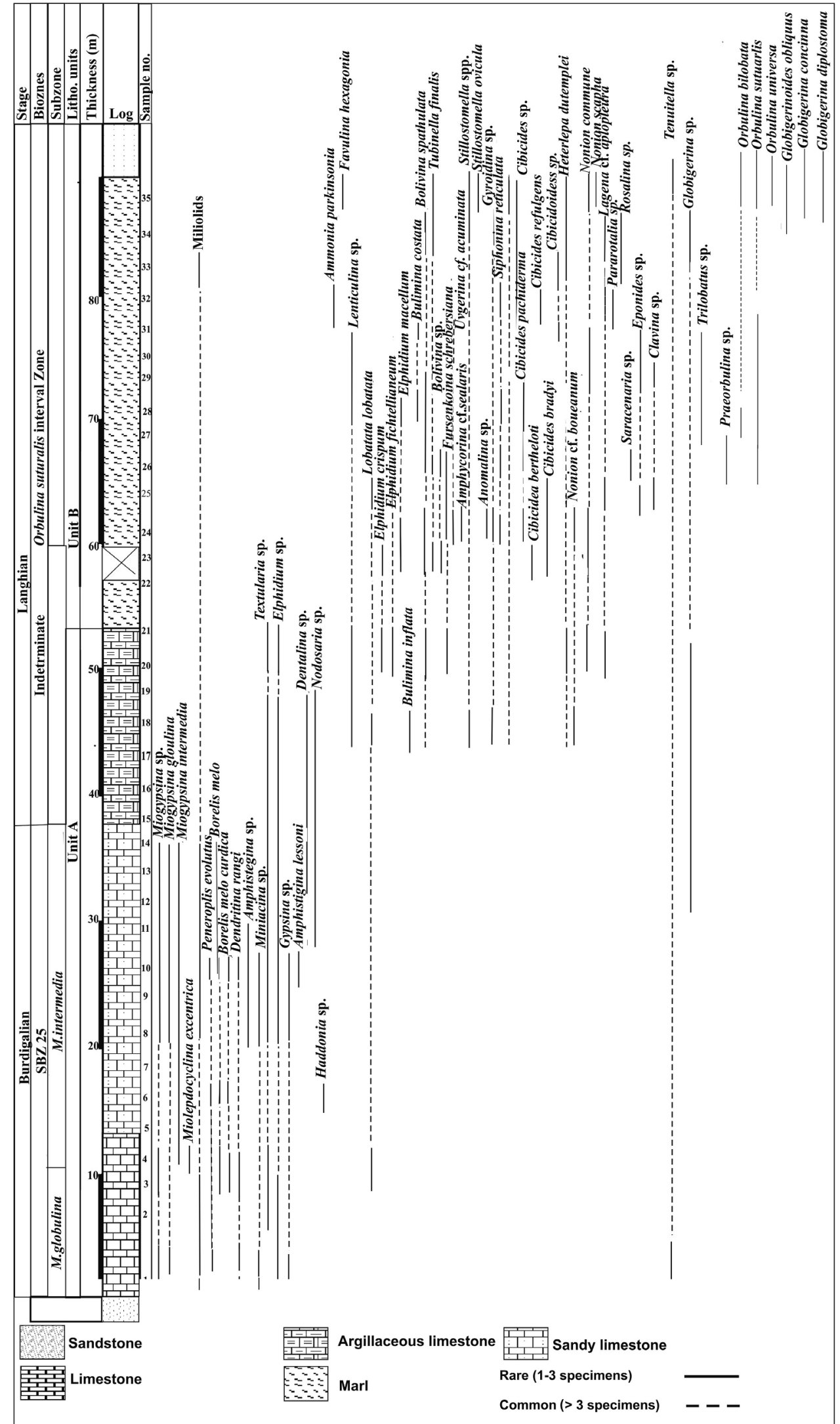

Fig. 4. Biostratigraphical chart of Miocene deposits at Sayl Cheshmeh. 


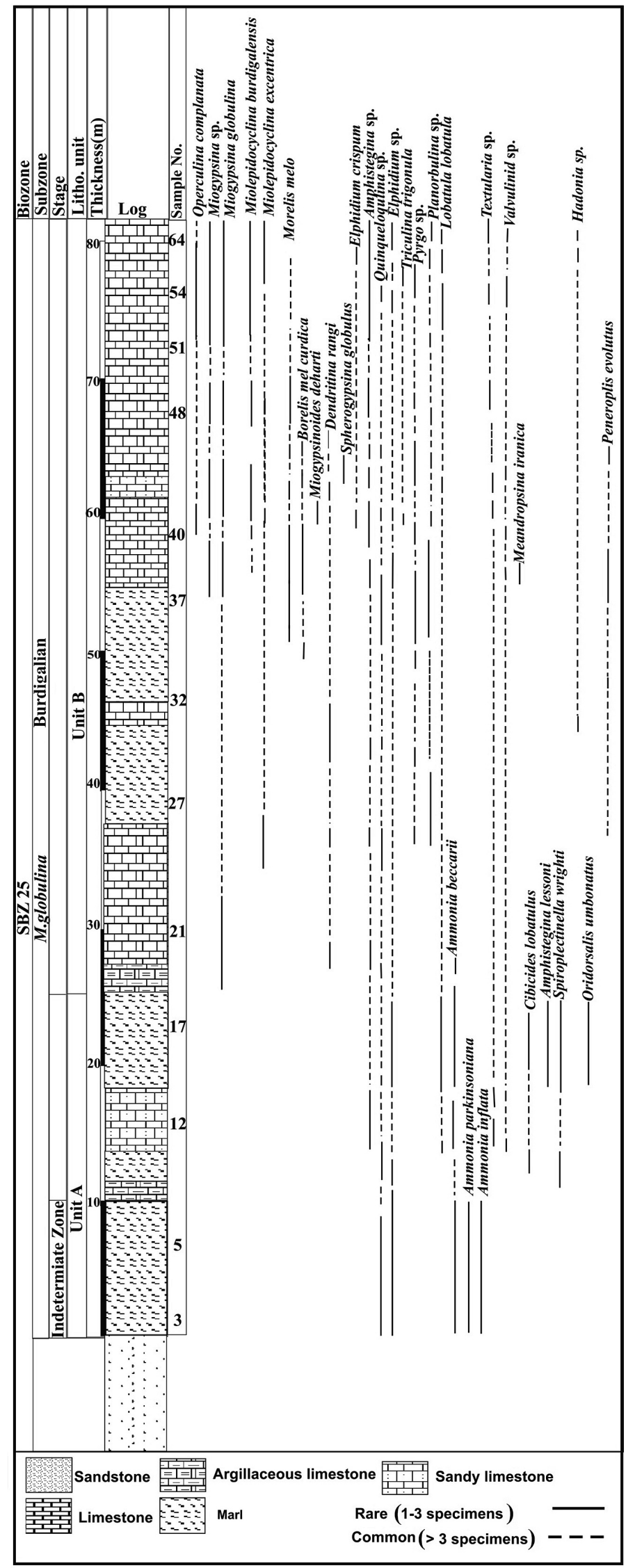

Fig. 5. Biostratigraphical chart of Miocene deposits at Mamole. 
Fig. 6. Biostratigraphical chart of Miocene deposits

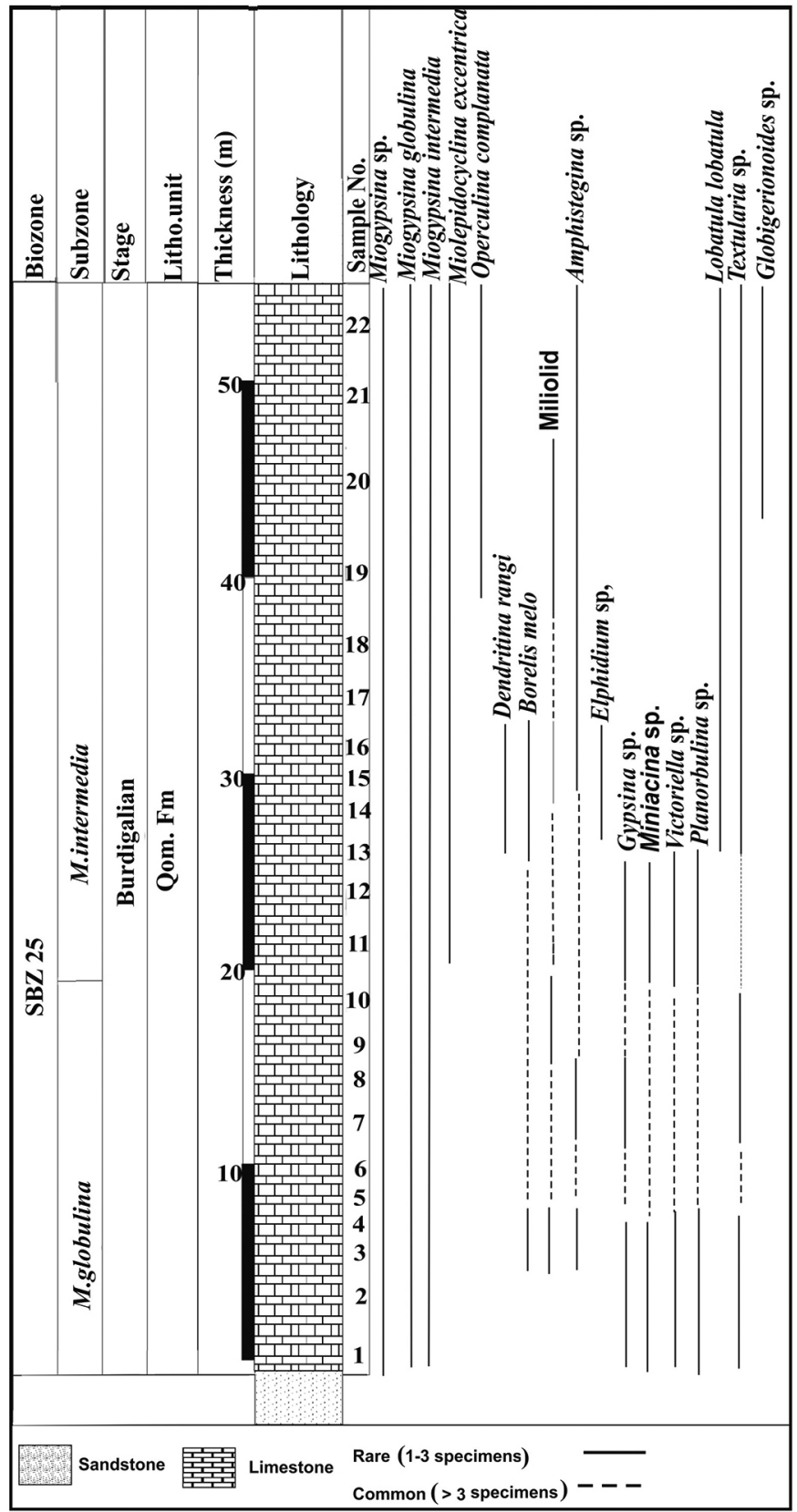
at Zarde Savar. 
per Te in the Far East (Te5) (Leupold \& Van der Vlerk, 1931). The thickness of strata assigned to this subzone amounts to 46 and 10 metres in the Mamole and Sayl Cheshmeh sections, respectively. The most significant benthic foraminifera recorded in this zone are Ammonia beccarrii (Linnaeus, 1758), A. tepida (Cushman, 1926), A. parkinsonia (d'Orbigny, 1839), Amphistegina lessonii (d'Orbigny, 1826), Borelis melo curdica (Reichel, 1937), B. melo (Fichtel \& Moll, 1798), Cibicides lobatulus (Walker \& Jacob, 1798), C. sp., Conorbella sp., Discorbis sp., Elphidium crispum (Linnaeus, 1758), Elphidium decipiens (O.G. Costa, 1856), Gypsina sp., Lobatula lobatula (Walker \& Jacob, 1798), Miniacina sp., Miolepidocyclina excentrica (Tan, 1937), Nonion commune (d'Orbigny, 1846), Oridorsalis umbonatus (Reuss, 1851), Peneroplis evolutus (Henson, 1950), Planorbulina sp., Pyrgo sp., Quinqueloculina sp., Rosalina sp., Sphaerogypsina globulus (Reuss, 1848), Spiroluculina sp., Spiroplectinella wright (Silvestri, 1903), Stomatorbina concentrica (Parker \& Jones, 1864), Triloculina tricarinata (d'Orbigny, 1826) and T. trigonula (Lamarck, 1804). The most important non-foraminifera of this zone are the Lithoporella melobesioides (Foslie, 1909), Lithothamnion sp. and Mesophyllum sp., as well as the ostracods Chrysocythere aff. naqibi (Khalaf, 1982), Cytheretta sp., Cyprideis sp., Miocyprideis ovalis (Khalaf, 1989), Sagmatocythere sp. and Xestoleberis aff. glabrescens (Reuss, 1850).

$2 b$. M. intermedia Subzone: This is defined by the stratigraphical range of $M$. intermedia, which is considered to be a characteristic form for the middle-upper Burdigalian. Its FO defines the base of the middle Burdigalian, while its LO coincides with that of the upper Burdigalian (Cahuzac \& Poignant, 1997; Boudagher-Fadel \& Price, 2010). This subzone is correlated with the Upper Te (Te5) (Leupold \& Van der Vlerk, 1931). The thickness of strata assigned to this subzone in the Mamole, Sayl Cheshmeh and Zardeh Savar sections amounts to 26, 26 and 30 metres, respectively. The most important foraminifera are: Amphistegina sp., Borelis melo curdica, Dendritina rangi (d'Orbigny, 1904), Discorbis sp., Elphidium sp., Haddonia sp., Miniacina sp., Gypsina sp., Miogypsinoides deharti (Van der Vlerk, 1924), M. burdigalensis (Gümbel, 1870), Miolepidocyclina excentrica (Tan, 1937), M. sp., Operculina complanata (Defrance, in de Blainville, 1822), Peneroplis evolutus, P. sp., Planorbulina sp., Pyrgo sp., Spiroluculina sp., Textularia sp., Uvigerina cf. acuminata (Hosius, 1895) and Victoriella sp. The most important non-foraminifera are the algae Amphiroa sp., Corallina sp., Lithoporella melobesioides (Foslie), Lithothamnion sp., Mesophyllum sp., Neogoniolithon sp. and Titanoderma sp.

3. Indeterminate zone: This zone spans 18 metres of clayey calcareous and marly sediments in the middle part of the Sayl Cheshmeh section. The boundary between this zone and one below reflects a clear ecological change, as documented by a turnover in benthic foraminiferal faunas. The most significant foraminifera recorded in this zone are: Anomalina sp., Bulimina sp., Cibicides bertheloti (d'Orbigny, 1839), Dentalina sp., Elphidium crispum (Linnaeus, 1758), E. fichtellianeum (d'Orbigny, 1846), E. macellum (Fichtel \& Moll, 1798), Elphidium sp., Nodosaria sp., Nonion cf. boueanum (d'Orbigny, 1846), N. scapha (Fichtel $\&$ Moll, 1798) and Globigerina sp. In view of the fact that we could not find any index microfossils in this zone, we here refer to it as indeterminate zone. As to its stratigraphical position, we prefer an early Langhian date for this zone. Planktonic foraminifera are frequent to dominant in the upper part of the Sayl Cheshmeh section. Based on their vertical distribution, a single biozone has been recognised:

4. Orbulina suturalis Interval Zone: this is defined by the FO of O. suturalis (Brönnimann, 1951) and ends right below the conglomerate/sandstone levels of Pliocene age. The zone comprises around 20 metres of the uppermost part of marly sediments in the Sayl Cheshmeh section. The FO of Orbulina suturalis (Brönnimann, 1951) was dated as 15.1 and 14.74 Ma by Berggren et al. (1995) and Laursen et al. (2009), respectively. As far as the Mediterranean area is concerned, this event was dated as 14.7 and 14.58-14.56 Ma (i.e., Langhian) by Foresi et al. (1998) and Abdul Aziz et al. (2008), respectively, and was used as an appropriate characteristic zone in Mediterranean biostratigraphy. The most diagnostic species include Globigerina concinna (Reuss, 1850), Globigerina diplostoma (Reuss, 1850), Globigerinoides obliquus (Bolli, 1957), Orbulina bilobata (d'Orbigny, 1846), O. universa (d'Orbigny, 1839), Orbulina sp. The Orbulina suturalis Interval Zone has been noted in biozonations for the Mediterranean Province ever since the work by Iaccarino (1985); it can be correlated with the Globorotalia peripheroronda/Orbulina suturalis Zone of Bizon \& Bizon (1972), the Orbulina suturalis Zone of Borsetti et al. (1979), the Orbulina suturalis Subzone of Iaccarino and Salvatorini (1982) and the Orbulina suturalis Zone of Berggren et al. (1995) and Wade et al. (2011). 
Fig. 7. Comparison of the Asmari Formation in sections studied with some regions of the HZTB and the Lorestan Basin.

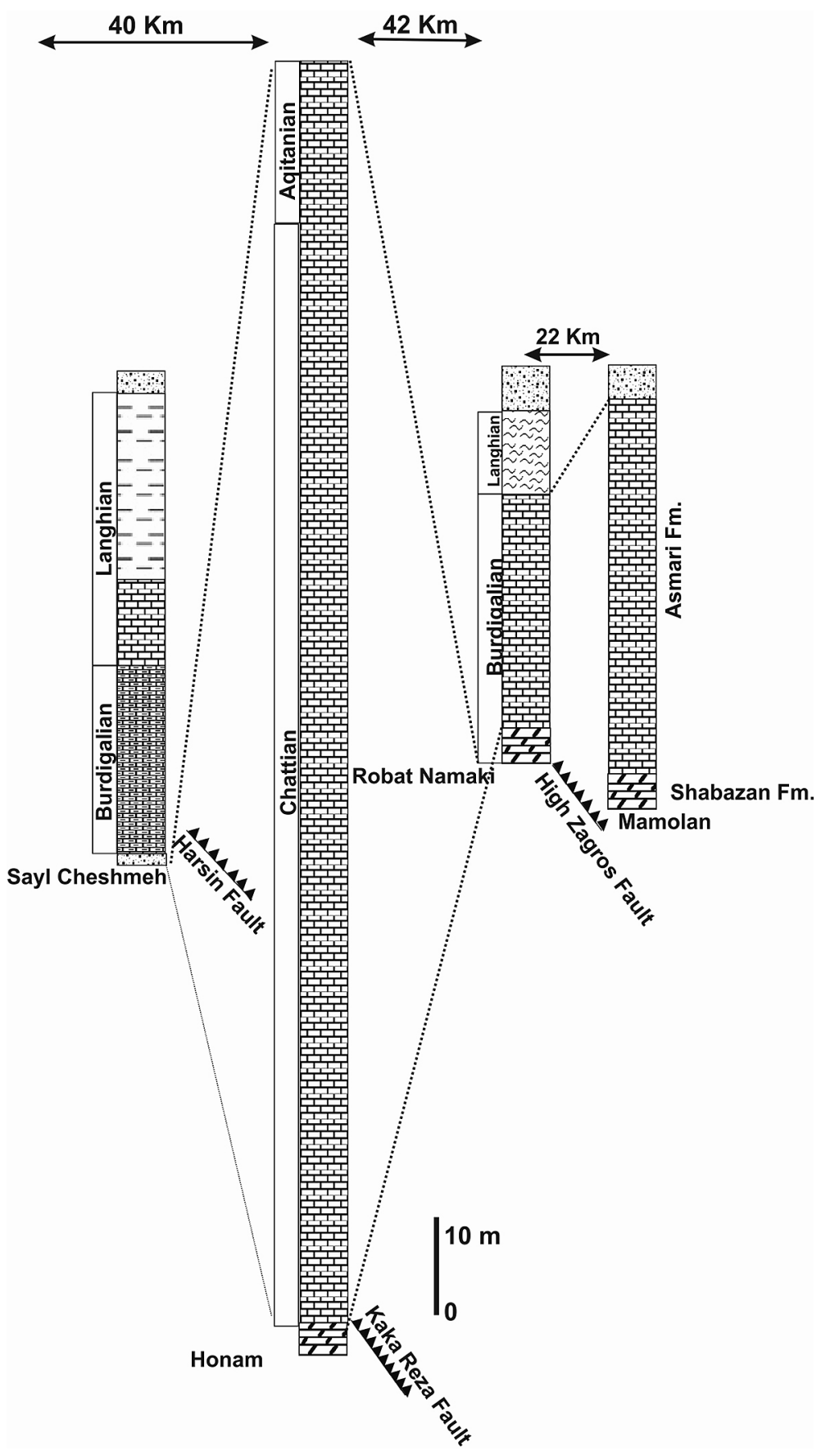




\section{Biostratigraphical correlation of Asmari Formation sections with adjacent areas}

James \& Wynd (1965) placed the FO of Borealis melo in the Burdigalian. Of this species, two subspecies are recognised: Boreli melo melo and B. melo curdi$c a$. The former evolved into the latter, which has a more complex structure of incipient attic chamberlets, a Y-shaped septula and external apertures (Jones et al., 2006). It is often difficult to differentiate these; in those cases, they are referred to as Borelis melo group (e.g., Daneshian \& Cheghini, 2007).

In the Indo-Pacific Province, Borelis melo melo starts in planktonic foraminiferal zone M1a (early Aquitanian) and continues up to M6 (late Langhian). However, its stratigraphical range in the Mediterranean Province is from the beginning of M5b (early Langhian) up to PL1 (early Pliocene) (Jones et al., 2006).

Borelis melo curdica appears in the Indo-Pacific Province in the middle of zone M5 (early Burdigalian) and becomes extinct near the top of M6 in the upper Langhian. In the Mediterranean Province, it ranges from the middle Burdigalian (upper M3) to the late Langhian (Jones et al., 2006). Based on Sr dating by Mossadegh et al. (2009) and Van Buchem et al. (2010), the FO of Borealis melo in the Dezful Embayment indicates an age no older than Burdigalian. The age of the LO of Borelis melo in Iran is problematic. In view of the fact that the evaporitic Gachsaran Formation and the molassic Upper Red Formation follow on strata woth Borealis in Zagros and central Iran, respectively, the LO of this species in Iran is affected by ecological conditions and its real stratigraphical range cannot be determined with certainty. However, in the Sayl Cheshmeh and Mamole sections, the FO and LO of $B$. melo is in SBZ25, indicating that the upper limit of this species, at least in the HZTB, precedes the end of the Burdigalian. Roozpeykar et al. (2019a, b) recorded Burdigalian to Langhian deposits in the Tang-e-Shabikhon and Robat Namaki sections, adjacent to the border between the HZTB and ZFTB (Fig. 1). These deposits unconformably overlie Eocene dolomites of the Shahbazan Formation and rest conformably on the Gachsaran Formation (Fig. 7). The Honam section, about $40 \mathrm{~km}$ to the south of the sections studied here, is $290 \mathrm{~m}$ in total thickness and comprises Chattian- Aquitanian limestones which rest unconformably on top of the Shahbazan Formation, while its upper boundary is covered (Mohammadi, 2014). In the northern parts of the Lorestan Basin, the Asmari Formation includes a shallow-marine deposit containing Borealis which rests unconformably on the Shahbazan Formation. Accordingly, the middle parts of the Lorestan Basin and the HZTB created palaeohighs between the Middle Eocene and Burdigalian and marine deposits formed only in a limited area of the HZTB (Honam section) during the Late Oligocene-Early Miocene. The boundary between these highs and troughs was coincident with tectonic trends, especially faults originating in the basement (e.g., High Zagros Fault). Heydari et al. (2013; for Bandar Abbas), Daneshian \& Ghanbari (2017; for Qom and Zanjan) and McCall (1985; for Makran) recorded Burdigalian-Langhian pelagic deposits, which corresponded to the Miocene deposits of the Sayl Cheshmeh section. The results obtained up to now show that, in general, deposition of all Burdigalian-Langhian pelagic strata in Iran occurred below $28^{\circ} 30^{\prime} \mathrm{N}$ (Bandar Abbas and Makran) and above $34^{\circ} \mathrm{N}$ in the HZTB (section studied) and central Iran (Qom and Zanjan). Following the Aquitanian marine carbonate deposition in central Iran and the Zagros Orogenic Belt, there was widespread emergence and continental conditions occurred between $28^{\circ} 30^{\prime} \mathrm{N}$ and $34^{\circ} \mathrm{N}$, and Neogene molasse sediments rest on a regional unconformity surface inherited from earlier movements.

Burdigalian-Langhian pelagic deposits extend into southern Turkey (Hüsing et al., 2009), where marine deposition lasted until the Tortonian. This deep area was probably affected by rising sea water levels during the Langhian (Cipollari et al., 2013). The Middle Miocene is considered as the warmest interval, its climatic maximum having been recorded for the interval of 17 to 5.13 myr ago (Zachos et al., 2001). This event resulted in increased nutrient input into the Mediterranean Province (Brandano et al., 2016) and can be correlated with the Monterey Event (Vincent \& Berger, 1985). The Middle Miocene marly deposits (in Sayl Chashmeh, Bandar Abbas, Makran and central Iran), with small benthic and planktonic foraminifera, indicates higher levels of organic matter and can thus be correlated well with Monterey Event.

\section{Conclusions}

1. Miocene deposits of north Nur Abad, along the northwestern margin of the HZTB, were studied for foraminiferal contents and biostratigraphy; the following conclusions can be drawn:

- The lower part of the sequence studied does not yield any index fossils and the age can only be based on its stratigraphical position; it is here considered to be Burdigalian. 
- The stratigraphical range of foraminifera in the sections studied is similar to that in the Mediterranean Province.

2. Based on the biostratigraphical range of microfossils identified, three bio-assemblages can be recognised:

- Larger benthic foraminiferal zones SBZ 25 (Miogypsina globulina-M. intermedia Zone): M. globuli$n a$ and $M$. intermedia subzones, considered to be of Burdigalian age.

- The middle parts of sections studied have not yielded any index fossils; its stratigraphical position is probably early Langhian.

- The Orbulina suturalis Interval Zone is of early Langhian age.

3. In previous biostratigraphical studies of Miocene deposits in the Zagros Orogenic Belt, only the $\mathrm{FO}$ of $B$. melo melo was mentioned; the age of the LO of this subspecies was problematic. Its LO in Iran was affected by ecological conditions, meaning that its true stratigraphical range is not clear. The FO and LO of Borelis melo in our sections conform to the early (not earliest) Burdigalian and pre-Burdigalian/Langhian boundary, respectively. This clearly indicates that the total range of $B$. melo melo, at least in the HZTB, is Burdigalian.

4. Our study and a comparison with previous studies shows that Burdigalian-Langhian pelagic deposits in Iran formed below $28^{\circ} 30^{\prime} \mathrm{N}$ and above $34^{\circ} \mathrm{N}$.

5. The distribution pattern of Miocene biozones in the HZTB follows fault trends.

6. Burdigalian-Langhian pelagic deposits at Sayl Cheshmeh and in other parts of Iran were affected by rising sea water levels and can be correlated with the Monterey Event.

\section{References}

Abbasi, G., Motamedi, H., Orang, K. \& Nickandish, A. A., 2020. Petroleum geology of the western part of the Central Iran Basin. Journal of Petroleum Geology 43, 171-190.

Abdul Aziz, H., Di Stefano, A., Foresi, L.M., Hilgen, F.J., Iaccarino, S.M., Kuiper, K.F., Lirer, F., Salvatorini, G., \& Turco, E., 2008. Integrated stratigraphy of early Middle Miocene sediments from DSDP Leg 42A Site 372 (western Mediterranean). Palaeogeography Palaeoclimatology Palaeoecology 257, 123-138.

Agard, P., Omrani, J., Jolivent, L., Whitechurch, H., Vrielynck, B., Spakman, W., Monié, P., Meyer, B. \& Wortel, R., 2011. Zagros orogeny: a subduction dominated process. Geological Magazine 148, 692-725.
Berberian, M. \& Yasini, A., 1983. Variations, facies extent and the principal guidelines of the paleogeography in Iran. [In:] M. Berberian (Ed.): Continental deformation in the Iranian plateau. Geological Survey of Iran, 72-73 (in Persian).

Berggren, W.A., Kent, D.V., Swisher, III.C.C. \& Aubry, M.P., 1995. A revised Cenozoic geochronology and chronostratigraphy. [In:] W.A. Berggren, D.V. Kent \& J. Hardenbol (Eds): Geochronology, time scale and global stratigraphic correlations: A unified temporal framework for an historical ecology. SEPM Special Publlication 54, 129-212.

Bizon, G. \& Bizon, J.J., 1972. Atlas des principaux foraminiferes planctoniques du basin méditerranéen. Oligocène à Quaternaire. Editions Technip, Paris, 316 pp.

Borsetti, A.M., Cati, F., Colalongo, M.L. \& Sartoni, S., 1979. Biostratigraphy and absolute ages of the Italian Neogene. $7^{\text {th }}$ International Conference Mediterranean Neogene, Athens, 183-197.

Boudagher-Fadel, M.K., \& Price, D., 2010. Evolution and paleogeographic distribution of the lepidocyclinids. Journal of Foraminifera Research 40, 79-108.

Brandano, M., Cornacchia, I., Raffi, I., \& Tomasseti, L., 2016. The Oligocene-Miocene stratigraphic evolution of the Majella carbonate platform (Central Apennines, Italy). Sedimentary Geology 333, 1-14.

Cahuzac, B., \& Poignant, A., 1997. An attempt of biozonation of the Oligo-Miocene in the European basins by means of larger neritic foraminifera. Bulletin de la Société géologique de France 168, 155-170.

Cipollari, P., Halasovas, E., Gürbüz, K., \& Cosentino, D., 2013. Middle-Upper Miocene paleogeography of southern Turkey: insights from stratigraphy and calcareous nannofossil biochronology of the Olukpinar and Başyayla sections (Mut-Ermenek Basin). Turkish Journal of Earth Sciences 22, 820-838.

Daneshian, J. \& Cheghini, A.R., 2007. Biostratigraphy of the Qom Formation in the Northeast and Southeast of Semnan. Geosciences 62, 72-79.

Daneshian, J. \& Ghanbari, M., 2017. Stratigraphic distribution of planktonic foraminifera from the Qom Formation: A case study from the Zanjan area (NW Central Iran). Neues Jahrbuch für Geologie und Paläontologie $283,239-254$.

Foresi, L.M., Iaccarino, S., Mazei, R. \& Salvatorini, G., 1998. New data on middle to late Miocene calcareous plankton biostratigraphy in the Mediterranean area. Riview Italiana Paleontology Stratigraphy 104, 114-195.

Heidari, A., Mahboubi, A., Moussavi-Harami, R., Gonzalez, L. \& Moalemi, S.A., 2013. Biostratigraphy, sequence stratigraphy, and paleoecology of the Lower-Middle Miocene of Northern Bandar Abbas, Southeast Zagros basin in south of Iran. Arabian Journal of Geosciences 7, 1829-1855.

Hüsing, S.K., Zachariasse, W., Van Hinsbergen, D.J.J., Krijgsmani, W., Inceöz, M., Harzhauser, M., Mandic, O. \& Kro, A., 2009. Oligocene-Miocene basin evolution in SE Anatolia,Turkey: constraints on the closure of the eastern Tethys gateway. The Geological Society London, Special Publications 311, 107-132. 
Iaccarino, S., 1985. Mediterranean Miocene and Pliocene planktonic foraminifera. [In:] H.M., Bolli, J.B., Saunders, \& K. Perch-Nielsen (Eds): Plankton Stratigraphy. Cambridge Univ. Press, 283-314.

Iaccarino, S. \& Salvatorini, G., 1982. A framework of planktonic foraminiferal biostratigraphy for Early Miocene to Late Pliocene Mediterranean area. Paleontology Stratigraphy Evolution 2, 115-125.

James, G.A. \& Wynd, J.G., 1965. Stratigraphic nomenclature of Iranian oil consortium, agreement area. American Association of Petroleum Geologists Bulletin 49, 2182-2245.

Jones, R.W., Simmons, M.D. \& Whittaker, J.E., 2006. On the stratigraphical and paleobiogeographical significance of Borelis melo melo (Fichtel and Moll, 1978) and B. melo curdica (Reichel, 1937) (Foraminifera, Miliolida, Alveolinidae). Journal of Micropaleontology 25, 175-185.

Khadivi, S., Mouthereau, F., Barbarand, J., Adatte, T. \& Lacombe, O., 2012. Constraints on palaeodrainage evolution induced by uplift and exhumation on the southern flank of the Zagros - Iranian Plateau. Journal of the Geological Society 169, 83-97.

Koop, W.J. \& Stoneley, R., 1982. Subsidence history of the Middle East Zagros Basin, Permian to recent. Philosophical Transactions of the Royal Society of London A 305, 149-168.

Laursen, G.V., Monibi, S., Allan, T.L., Pickard, N.A.H., Hosseiney, A., Vincent, B., Hamon, Y., van Buchem, F.S.P., Moallemi, A. \& Druillion, G., 2009. The Asmari Formation revisited: changed stratigraphic allocation and new biozonation. [In:] First International Petroleum Conference and Exhibition, Shiraz, Iran.

Leupold, W. \& Van Der Vlerk, I.M., 1931. The Tertiary. Leiden Geologischen Mededeelingen 5, 611-648.

McCall, G.J.H., 1985. Area Report, East Iran Project. Geological Survey of Iran, No. 1, Report no. 57, 1.

Mohammadi, A., 2014. Biostratigraphy and sequence stratigraphy of the Asmari Formation in north and southwest of Khorram Abad. Lorestan University, 74 pp.

Mossadegh, Z.K., Haig, D.W., Allan, T., Adabi, M.H., \& Sadeghi, A., 2009., Salinity changes during Late Oligocene to Early Miocene Asmari Formation deposition, Zagros Mountains, Iran: Palaeogeography, Palaeoclimatology, Palaeoecology 272, 17-36.

Motiei, H., 1993. Treatise on geology of Iran, stratigraphy of Zagros. Geological Survey of Iran, Tehran, $346 \mathrm{pp}$.

Murray, J.W., 1991. Ecology and distribution of benthonic foraminifera. [In:] J.J. Lee, \& R.O. Anderson (Eds): Biology of Foraminifera. Academic Press, London, 221284.

Özcan, E. \& Less, G.Y., 2009. First record of the co-occurrence of Western Tethyan and Indo-Pacific larger foraminifera in the Burdigalian of the Mediterranean province. Journal of Foraminiferal Research 39, 23-39.

Reuter, M., Piller, W.E., Harzhauser, M., Mandic, O., Berning, B., Rogl, F., Kroh, A., Aubry, M.P., Wielandt-Schuster, U. \& Hamedani, A., 2008. The Oligo-Miocene Qom Formation (Iran): evidence for an early Burdigalian restriction of Tethyan Seaway and closure of its Iranian gateways. International Journal of Earth Sciences 98, 627-650.

Roozpeykar, A., Maghfouri Moghaddam, I., Yazdi, M. \& Yousefi Yeghaneh, B., 2019a. Facies and paleoenvironmental reconstruction of Early-Middle Miocene deposits in the north-west of the Zagros Basin, Iran. Geologica Carpathica 70, 75-87.

Roozpeykar, A., Maghfouri Moghaddam,I., Yazdi, M. \& Yousefi Yeghaneh, B., 2019b. Paleontology and paleoecology of coralline algal assemblages from the Early-Middle Miocene deposits in NW of the Zagros basin Iran. Carbonate Evaporite 34, 1595-1618.

Shahidi, M. \& Nazari, H., 1997. Geological map of Harsin, 1/100.000 scale. Geological survey of Iran.

Sherkaty, S. \& Letouzey, J., 2004. Variation of structural style and basin evolution in the Central Zagros (Izeh zone and Dezful beltl Iran). Marine and Petroleum Geology 21, 35-554.

Thomas, A.N., 1950. The Asmari Limestone of Southwest Iran. Report. $18^{\text {th }}$ International Geological Congress, London, 35-55.

Thomas, A.N., 1952. Facies variation in Asmari Limestone. With discussion. International Geological Congress, London, 74- 82.

Van Buchem, F.S.P., Allan, T.L., Laursen, G.V., Lotfpour, M., Moallemi, A., Monibi Motiei, H., Pickard, N.A.H., Tahmasbi, A.R., Vedrenne, V. \& Vincent, B., 2010. Regional stratigraphic architecture and reservoir types of the Oligo-Miocene deposits in the Dezful Embayment (Asmari and Pabdeh Formations) SW Iran. Geological Society, London, Special Publications 329, 219-263.

Vincent, E. \& Berger, W.H., 1985. Carbon dioxide and polar cooling in the Miocene. The Monterey Hypothesis in the carbon cycle and atmospheric $\mathrm{CO}$ natural variations. Archean to Present. Geophysical Monograph Series 32, 455-468.

Wade, B.S., Pearson, P., Berggren, W.A. \& Pälike, H., 2011. Review and revision of Cenozoic tropical planktonic foraminiferal biostratigraphy and calibration to the geomagnetic polarity and astronomical time scale. Earth Science Review 104, 111-142.

Zachos, J., Pagani, M., Sloan, L., Thomas, E. \& Billups, K., 2001. Trends, rhythms and aberrations in global climate 65 Ma to present. Science 292, 686-692.

Manuscript received: 3 June 2020 Revision accepted: 15 July 2021 